\title{
FAKTOR-FAKTOR YANG MEMPENGARUHI PEMANFAATAN POS PEMBINAAN TERPADU OLEH LANSIA
}

\author{
*Nurul Misbah, *Ayi Tansah Rohaeti
}

\begin{abstract}
Abstrak
Jumlah penduduk Lansia Indonesia pada tahun 2020, berdasarkan proyeksi penduduk Indonesia 2000-2025 diperkirakan akan mencapai 28,99 juta jiwa. Peningkatan jumlah Lansia menjadi salah satu indikator keberhasilan pembangunan sekaligus sebagai tantangan dalam pembangunan. Bila permasalahan tersebut tidak diantisipasi dari sekarang, maka tidak tertutup kemungkinan bahwa proses pembangunan akan mengalami berbagai hambatan. Seiring dengan semakin meningkatnya populasi lansia, pemerintah telah merumuskan berbagai kebijakan pelayanan kesehatan lansia ditujukan untuk meningkatkan derajat kesehatan dan mutu kehidupan lansia berupa Posyandu Lansia (Pos Pembinaan Terpadu), namun pemanfaatannya di masyarakat belum optimal.

Tujuan penelitian iniUntuk mengetahui faktor-faktor yang mempengaruhi pemanfaatan Pos pembinaan terpadu oleh Lansia di desa Padasuka wilayah kerja Puskesmas Kecamatan Warunggunung Kabupaten Lebak tahun 2015.Jenis penelitian ini adalah deskriptif analitik dengan pendekatan cross sectional. Jumlah sampel yaitu total populasi sebanyak 68 lansia.Pengambilan data dilakukan dengan mengisi kwisioner dan wawancara. Analisis data dengan univariat, dan bivariat.

Hasil analisis univariat menunjukkan bahwa Sebagian besar(60,6\%) lansia kurang memanfaatkan Posbindu, sebagian besar $(59,1 \%)$ lansia memiliki umur 4559 tahun (Pra Lansia),hampir seluruhnya $(92,4 \%)$ tingkat pendidikan lansia rendah,sebagian kecil $(30,3 \%)$ sikap lansia terhadap posbindu negatif,hampir setengahnya $(48,5 \%)$ lansia kurang mendapat dukungan keluarga. Sedangkan hasil analisis bivariat menunjukkanterdapat hubungan yang bermanakna antara jenis kelamin, pengetahuan, sikap dan dukungan keluarga dengan pemanfaatan Posbindu dan tidak terdapat hubungan yang bermanakna antara umur dan pendidian dengan pemanfaatan Posbindu di Desa Padasuka Wilayah Kerja Puskesmas Warunggunung tahun 2015.

Seiring dengan meningkatnya Umur Harapan Hidup dan jumlah Usila lanjut bagi Dinas Kesehatan Kabupaten Lebak hendaknya membuat kebijakan untuk mewujudkan program Posbindu secara merata di setiap desa.Dinas kesehatan dalam hal ini Puskesmas, hendaknya melakukan advokasi ke tingkat desa guna mengadakan sarana dan prasarana Posbindu minimal setiap RW memiliki satu buah Posbindu.
\end{abstract}

Kata Kunci : Pemanfaatan Posbindu, Puskesmas Warungunung

*Poltekkes Kemenkes Banten 
Pendahuluan

Meningkatnya umur harapan hidup (UHH) adalah salah satu indikator utama tingkat kesehatan masyarakat.Semakin tinggi jumlah Lansia, maka semakin baik tingkat kesehatan masyarakatnya. Jumlah penduduk Lansia Indonesia pada tahun 2020, berdasarkan proyeksi penduduk Indonesia 2000-2025 diperkirakan akan mencapai 28,99 juta jiwa (http://www.datastatistikindonesia.com).

Proses penuaan penduduk tentunya berdampak pada berbagai aspek kehidupan, baik sosial, ekonomi, dan terutama kesehatan, karena dengan semakin bertambahnya usia, fungsi organ tubuh akan semakin menurun baik karena faktor alamiah maupun karena penyakit. Dengan demikian, peningkatan jumlah Lansia menjadi salah satu indikator keberhasilan pembangunan sekaligus sebagai tantangan dalam pembangunan. Bila permasalahan tersebut tidak diantisipasi dari sekarang, maka tidak tertutup kemungkinan bahwa proses pembangunan akan mengalami berbagai hambatan .
Mengingat kondisi dan permasalahan Lansia tersebut, maka penanganan masalah Lansia harus menjadi prioritas, karena permasalahannya terus berpacu dengan pertambahan jumlahnya.Seiring dengan semakin meningkatnya populasi Lansia, pemerintah telah merumuskan berbagai kebijakan pelayanan kesehatan Lansia ditujukan untuk meningkatkan derajat kesehatan dan mutu kehidupan Lansia untuk mencapai masa tua bahagia dan berdaya guna dalam kehidupan keluarga dan masyarakat sesuai dengan keberadaannya.

Sebagai wujud nyata pelayanan sosial dan kesehatan pada kelompok Lansia, pemerintah telah mencanangkan pelayanan pada Lansia melalui beberapa jenjang.Pelayanan kesehatan di tingkat masyarakat adalah Posyandu Lansia, pelayanan kesehatan Lansia tingkat dasar adalah Puskesmas, dan pelayanan kesehatan tingkat lanjutan adalah Rumah Sakit.

Sebagai pelayanan kesehatan di tingkat masyarakat, Posyandu Lansia memiliki arti penting.Sama halnya 
dengan posyandu balita Posyandu Lansia adalah kegiatan kesehatan dasar untuk para Lansia yang diselenggarakan dari, oleh dan untuk masyarakat yang dibantu oleh petugas kesehatan.Jadi, Posyandu Lansia merupakan kegiatan swadaya dari masyarakat di bidang kesehatan dengan penanggung jawab kepala desa. Pelayanan kesehatan Lansia yang dimaksudkan adalah penduduk usia 45 tahun ke atas yang mendapatkan pelayanan kesehatan sesuai standar oleh tenaga kesehatan baik di Puskesmas maupun di Posyandu Kelompok Lansia.

Pada bulan Februari 2015 jumlah Lansia Di Wilayah Kerja Puskesmas Kecamatan Warunggunung sebesar 3.844 orang. Hasil kegiatan pelayanan kesehatan Lansia di Wilayah kerja Puskesmas Kecamatan Warunggunung Kabupaten Lebak, hanya ada dua Posbindu/Posyandu Lansia yang dikelola dengan baik, yaitu di Desa Padasuka dan Desa Sukarendah yang telah melaksanakan pelayanan kesehatan sesuai standar. Di Desa Padasuka Lansia berjumlah 334 lansia dan yang memanfaatkan Posbindu hanya sebesar 66 lansia.

Penelitian bertujuan untuk mengetahui faktor-faktor yang mempengaruhi pemanfaatan Pos pembinaan terpadu oleh Lansia Di Desa Padasuka Wilayah kerja Puskesmas

Kecamatan Warunggunung Kabupaten Lebak tahun 2015.

\section{Metode Penelitian}

Desain penelitian menggunakan pendekatan cross sectional. Pendekatan cross sectional.Instrumen pengumpulan data yang digunakan pada penelitian ini adalah kuisioner.Populasi dan sampel pada penelitian ini adalah pra Lansia dan Lansia yang memanfaatkan/terdaftar di Posbindu Di Desa Padasuka Wilayah kerja Puskesmas Kecamatan Warunggunung pada bulan Agustus dan September 2015 berjumlah 66 orang. Data yang terkumpul selanjutnya diolah dan dianalisis secara univariat dan bivariat 


\section{Hasil Penelitian}

Analisis Univariat :

Tabel 1

Distribusi Frekuensi Lansia Berdasarkan Pemanfaatan Posbindu

Di Desa PadasukaWilayah Kerja

Puskesmas Warunggunung Tahun 2015

\begin{tabular}{lcc}
\hline Variabel & Frekuensi & Persen \\
\hline Kurang & 40 & 60,6 \\
Baik & 26 & 39,4 \\
Jumlah & 66 & 100 \\
\hline
\end{tabular}

Pada tabel 1 menunjukkan bahwa sebagian besar lansia kurang memanfaatkan Posbindu (60,6\%).

2.Umur

Tabel 2

Distribusi Frekuensi Lansia Berdasarkan Umur Di Desa Padasuka Wilayah Kerja Puskesmas Kecamatan Warunggunung kabupaten Lebak Tahun 2015

\begin{tabular}{lcc}
\hline Umur & Frekuensi & Persen \\
\hline $45-59$ tahun & 39 & 59,1 \\
$>60$ tahun & 27 & 40,9 \\
\hline Jumlah & 66 & 100 \\
\hline
\end{tabular}

Pada tabel 2 menunjukkan bahwa lansia sebagian besar memiliki umur 45-59 tahun $(59,1 \%)$.

\section{Jenis Kelamin}

Tabel 3

Distribusi Frekuensi Lansia Berdasarkan Jenis Kelamin Di Desa Padasuka Wilayah Kerja Puskesmas Kecamatan Warunggunung Kabupaten Lebak Tahun 2015

\begin{tabular}{lcc}
\hline Jenis Kelamin & Frekuensi & Persen \\
\hline Laki-laki & 17 & 25,8 \\
Perempuan & 49 & 74,2 \\
\hline Jumlah & 66 & 100 \\
\hline
\end{tabular}

Pada tabel 3 menunjukkan bahwa sebagian kecil lansia memiliki jenis kelamin laki-laki $(25,8 \%)$.

\section{Pendidikan}

Tabel 4

Distribusi Frekuensi Lansia Berdasarkan Pendidikan Di Desa Padasuka Wilayah Kerja Puskesmas Kecamatan Warunggunung Kabupaten Lebak Tahun 2015

\begin{tabular}{lcc}
\hline Pendidikan & Frekuensi & Persen \\
\hline Rendah & 61 & 92,4 \\
Tinggi & 5 & 7,6 \\
\hline Jumlah & 66 & 100 \\
\hline
\end{tabular}

Pada tabel 4 menunjukkan bahwa hampir seluruhnya tingkat pendidikan lansia rendah $(92,4 \%)$. 
5. Pengetahuan

Tabel 5

Distribusi Frekuensi Lansia

Berdasarkan Pengetahuan Di Desa

Padasuka Wilayah Kerja Puskesmas

Kecamatan Warunggunung

Kabupaten Lebak Tahun 2015

\begin{tabular}{lcc}
\hline Pengetahuan & Frekuensi & Persen \\
\hline Kurang & 17 & 25,8 \\
Baik & 49 & 74,2 \\
\hline Jumlah & 66 & 100
\end{tabular}

Pada tabel 5 menunjukkan bahwa sebagian kecil tingkat pengetahuan lansia kurang $(25,8 \%)$.

6. Sikap

Tabel 6

Distribusi Frekuensi Lansia Berdasarkan Sikap Di Desa Padasuka

Wilayah Kerja Puskesmas

Kecamatan Warunggunung

Kabupaten Lebak Tahun 2015

\begin{tabular}{lcc}
\hline Sikap & Frekuensi & Persen \\
\hline Negatif & 20 & 30,3 \\
Positif & 46 & 69,7 \\
\hline Jumlah & 66 & 100 \\
\hline
\end{tabular}

Pada tabel 6 diatas menunjukkan bahwa masih banyak $(30,3 \%)$ lansia memiliki sikap negatif $(30,3 \%)$.
7. Dukungan Keluarga

Tabel 7

Distribusi Frekuensi Lansia

Berdasarkan Dukungan Keluarga Di

Desa Padasuka Wilayah Kerja

Puskesmas Kecamatan

Warunggunung

Kabupaten Lebak Tahun 2015

\begin{tabular}{lcc}
\hline $\begin{array}{l}\text { Dukungan } \\
\text { Keluarga }\end{array}$ & Frekuensi & Persen \\
\hline Kurang & 32 & 48,5 \\
Baik & 34 & 51,5 \\
\hline Jumlah & 66 & 100 \\
\hline
\end{tabular}

Pada tabel 7 diatas menunjukkan bahwa hampir setengahnya lansia kurang mendapat dukungan keluarga $(48,5 \%)$.

Analisis Bivariat

1. Hubungan Umur Dengan Pemanfaatan Posbindu Oleh Lansia.

Tabel 8

Hubungan Umur Dengan Pemanfaatan Posbindu Oleh Lansia Di Ds Padasuka Wil Kerja Puskesmas Kecamatan Warunggunung Kabupaten Lebak Tahun 2015

\begin{tabular}{rcccc}
\hline \multirow{2}{*}{ Umur } & \multicolumn{2}{c}{$\begin{array}{c}\text { Pemanfaatan } \\
\text { Posbindu }\end{array}$} & Jumlah & P Value \\
\cline { 2 - 3 } & kurang & baik & & \\
\hline \multirow{2}{*}{$45-59$ th } & $\begin{array}{c}23 \\
(59,0 \%)\end{array}$ & $\begin{array}{c}16 \\
(41,0 \%)\end{array}$ & $\begin{array}{c}39 \\
(100 \%)\end{array}$ & \\
\hline \multirow{2}{*}{$>60$ th } & 17 & 10 & 27 & 0,744 \\
& $(63,0 \%)$ & $(37,0 \%)$ & $(100 \%)$ & \\
\hline \multirow{2}{*}{ Jumlah } & $\begin{array}{c}40 \\
(60,6 \%)\end{array}$ & $\begin{array}{c}26 \\
(39,4 \%)\end{array}$ & $\begin{array}{c}66 \\
(100 \%)\end{array}$ & \\
\hline
\end{tabular}


Dari tabel 8 diatas Dari tabel 9diatas menunjukkan bahwa lansia yang kurang memanfaatkan Posbindu proporsinya sedikit lebih besar padalansia yang memiliki umur $>60$ tahun $(63,0 \%)$ dibandingkan pada lansia yang memiliki umur 45-59 tahun (Pra lansia) (59,0\%).

Hasil uji ststistik dengan mengunakan uji Chi Square pada $\alpha$ $=0,05$ didapatkan nilai $\mathrm{P}$ sebesar $0,744(\mathrm{P}>0,05)$ yang berarti bahwa secara statistik tidak terdapat hubungan yang bermakna antara umur dengan pemanfaatan Posbindu oleh lansia di Desa Padasuka Kecamatan Warunggunung tahun 2015 .

2. Hubungan Jenis Kelamin Dengan Pemanfaatan Posbindu Oleh Lansia.

\section{Tabel 9}

Hubungan Jenis Kelamin Dengan Pemanfaatan Posbindu Oleh Lansia Di Ds Padasuka Wil Kerja Puskesmas Kecamatan Warunggunung Kabupaten Lebak Tahun 2015

\begin{tabular}{lccccc}
\hline \multirow{2}{*}{$\begin{array}{c}\text { Jenis } \\
\text { kelamin }\end{array}$} & \multicolumn{2}{c}{$\begin{array}{c}\text { Pemanfaatan } \\
\text { Posbindu }\end{array}$} & \multirow{2}{*}{$\begin{array}{c}\text { Jum } \\
\text { lah }\end{array}$} & $\begin{array}{c}\text { P } \\
\text { Value }\end{array}$ & OR \\
\cline { 2 - 4 } & kurang & baik & & \\
\hline Laki- & 15 & 2 & 17 & & \\
laki & $(88.2 \%)$ & $(11.8 \%)$ & $(100 \%)$ & & \\
\cline { 1 - 4 } Perem- & 25 & 24 & 49 & 0,007 & 7,20 \\
puan & $(51.0 \%)$ & $(49.0 \%)$ & $(100 \%)$ & & \\
\hline \multirow{2}{*}{ Jumlah } & 40 & 26 & 66 & & \\
& $(60.6 \%)$ & $(39.4 \%)$ & $(100 \%)$ & \\
\hline
\end{tabular}

menunjukkan bahwa kurangnya pemanfaatan Posbindu oleh Lansia proporsinya lebih besar pada lansia yang memiliki jenis kelamin lakilaki(88,2\%) dibandingkan padalansia yang memiliki jenis kelamin perempuan $(51,0 \%)$.

Hasil uji ststistik dengan mengunakan uji Chi Square pada $\alpha$ $=0,05$ didapatkan nilai $\mathrm{P}$ sebesar $0,007 \quad(\mathrm{P}<0,05)$ yang berarti bahwa secara statistik terdapat hubungan yang bermakna antara jenis kelamin dengan pemanfaatan Posbindu oleh lansia di Desa Padasuka Kecamatan Warunggunung tahun 2015.

Adapun nilai OR (Odds Ratio) yang diperoleh dalam penelitian ini sebesar 7,200. Hal ini dapat dikatakan bahwa lansia yang memiliki jenis kelamin laki-laki cenderung memiliki resiko 7 kali lebih besar untuk tidak memanfaatkan Posbindu Lansia dibandingkan dengan lansia yang memiliki jenis kelamin perempuan. 
3. Hubungan Pendidikan Dengan

Pemanfaatan PosbinduOleh

Lansia.

Tabel 10

Hubungan Pendidikan Dengan

Pemanfaatan Posbindu Oleh Lansia

Di Ds Padasuka Wil Kerja Puskesmas

Kecamatan Warunggunung

Kabupaten Lebak Tahun 2015

\begin{tabular}{ccccc}
\hline \multirow{2}{*}{$\begin{array}{c}\text { Pendidi } \\
\text { kan }\end{array}$} & \multicolumn{2}{c}{$\begin{array}{c}\text { Pemanfaatan } \\
\text { Posbindu }\end{array}$} & \multirow{2}{*}{$\begin{array}{c}\text { Jumla } \\
\text { hunnnn}\end{array}$} & P Value \\
\cline { 2 - 4 } kurang & baik & & \\
\hline \multirow{2}{*}{ Rendah } & 38 & 23 & 61 & \\
& $(62.3 \%)$ & $(37,7 \%)$ & $(100 \%)$ & \\
\cline { 2 - 4 } Tinggi & 2 & 3 & 5 & \multirow{2}{*}{0,007} \\
& $(40.0 \%)$ & $(60.0 \%)$ & $(100 \%)$ & \\
\hline \multirow{2}{*}{ Jumlah } & 40 & 26 & 66 & \\
& $(60.6 \%)$ & $(39.4 \%)$ & $(100 \%)$ & \\
\hline
\end{tabular}

Dari tabel 10 diatas menunjukkan bahwa lansia yang kurang memanfaatkan Posbindu proporsinya lebih besar pada lansia yang memiliki pendidikan rendah (62.3\%) dibandingkan pada lansia yang memiliki pendidikan tinggi $(40.0 \%)$.

Hasil uji ststistik dengan mengunakan uji Chi Square pada $\alpha$ $=0,05$ didapatkan nilai $\mathrm{P}$ sebesar 0,327 (P>0,05) yang berarti bahwa secara statistik tidak terdapat hubungan yang bermakna antara pendidikan dengan pemanfaatan Posbindu oleh lansia di Desa Padasuka Kecamatan Warunggunung tahun 2015.

\section{Hubungan Pengetahuan Dengan Pemanfaatan PosbinduOleh Lansia.}

Tabel 11

Hubungan Pengetahuan Dengan Pemanfaatan Posbindu Oleh Lansia Di Ds Padasuka Wil Kerja Puskesmas Kecamatan Warunggunung Kabupaten Lebak Tahun 2015

\begin{tabular}{|c|c|c|c|c|c|}
\hline \multirow{2}{*}{$\begin{array}{c}\text { Pengeta } \\
\text { huan }\end{array}$} & \multicolumn{2}{|c|}{$\begin{array}{c}\text { Pemanfaatan } \\
\text { Posbindu }\end{array}$} & \multirow{2}{*}{$\begin{array}{l}\text { Jum } \\
\text { lah }\end{array}$} & \multirow{2}{*}{$\begin{array}{c}\mathrm{P} \\
\text { Value }\end{array}$} & \multirow[t]{2}{*}{ OR } \\
\hline & kurang & baik & & & \\
\hline Kurang & $\begin{array}{c}16 \\
(94,1 \%) \\
\end{array}$ & $\begin{array}{c}1 \\
(5,9 \%) \\
\end{array}$ & $\begin{array}{c}17 \\
(100 \%) \\
\end{array}$ & \multirow{3}{*}{0,003} & \multirow{3}{*}{$\begin{array}{c}16,67 \\
(2,048 \\
- \\
135,6 \\
26)\end{array}$} \\
\hline Baik & $\begin{array}{c}24 \\
(49.0 \%)\end{array}$ & $\begin{array}{c}25 \\
(51,0 \%)\end{array}$ & $\begin{array}{c}49 \\
(100 \%) \\
\end{array}$ & & \\
\hline Jumlah & $\begin{array}{c}40 \\
(60.6 \%) \\
\end{array}$ & $\begin{array}{c}26 \\
(39.4 \%) \\
\end{array}$ & $\begin{array}{c}66 \\
(100 \%) \\
\end{array}$ & & \\
\hline
\end{tabular}

Dari tabel 11 diatas menunjukkan bahwa lansia yang kurang memanfaatkan Posbindu proporsinya lebih besar pada lansia yang memiliki pengetahuan kurang (94.1\%) dibandingkan pada lansia yang memiliki pengetahuan baik $(49.0 \%)$.

Hasil uji ststistik dengan mengunakan uji Chi Square pada $\alpha$ $=0,05$ didapatkan nilai $\mathrm{P}$ sebesar $0,001 \quad(\mathrm{P}<0,05)$ yang berarti bahwa secara statistik terdapat hubungan yang bermakna antara pengetahuan dengan pemanfaatan Posbindu oleh lansia di Desa Padasuka Kecamatan Warunggunung tahun 2015. 
Adapun nilai OR (Odds Ratio)

yang diperoleh dalam penelitian ini sebesar 16,667. Hal ini dapat dikatakan bahwa lansia yang memiliki pengetahuan kurang cenderung memiliki resiko hampir 17 kali lebih besar untuk tidak memanfaatkan Posbindu Lansia dibandingkan dengan lansia yang memiliki pengetahuan baik.

5. Hubungan Sikap Dengan

Pemanfaatan PosbinduOleh Lansia.

Tabel 12

Hubungan Sikap Dengan

Pemanfaatan Posbindu Oleh Lansia

Di Ds Padasuka Wil Kerja Puskesmas

Kecamatan Warunggunung Kabupaten Lebak Tahun 2015

\begin{tabular}{|c|c|c|c|c|c|}
\hline \multirow[t]{2}{*}{ Sikap } & \multicolumn{2}{|c|}{$\begin{array}{l}\text { Pemanfaatan } \\
\text { Posbindu }\end{array}$} & \multirow{2}{*}{$\begin{array}{l}\text { Jum } \\
\text { lah }\end{array}$} & \multirow{2}{*}{$\begin{array}{c}\mathrm{P} \\
\text { Value }\end{array}$} & \multirow[t]{2}{*}{ OR } \\
\hline & kurang & baik & & & \\
\hline Negatif & $\begin{array}{c}17 \\
(85,0 \%)\end{array}$ & $\begin{array}{c}3 \\
(15,0 \%)\end{array}$ & $\begin{array}{c}20 \\
(100 \%)\end{array}$ & \multirow{3}{*}{0,016} & \multirow{3}{*}{$\begin{array}{c}5,67 \\
(1,46- \\
22.01)\end{array}$} \\
\hline Positif & $\begin{array}{c}23 \\
(50.0 \%)\end{array}$ & $\begin{array}{c}25 \\
(50,0 \%)\end{array}$ & $\begin{array}{c}46 \\
(100 \%) \\
\end{array}$ & & \\
\hline Jumlah & $\begin{array}{c}40 \\
(60.6 \%)\end{array}$ & $\begin{array}{c}26 \\
(39.4 \%)\end{array}$ & $\begin{array}{c}66 \\
(100 \%)\end{array}$ & & \\
\hline
\end{tabular}

$$
\text { Dari tabel 12diatas }
$$

menunjukkan bahwa Lansia yang kurang memanfaatkan Posbindu proporsinya lebih banyak pada lansia yang memiliki sikap negatif(85.0\%) dibandingkan padalansia yang memiliki sikap positif (50.0\%).
Hasil uji ststistik dengan mengunakan uji Chi Square pada $\alpha$ $=0,05$ didapatkan nilai $\mathrm{P}$ sebesar 0,007 ( $<<0,05)$ yang berarti bahwa secara statistik terdapat hubungan yang bermakna antara sikap dengan pemanfaatan Posbindu oleh lansia di Desa Padasuka Kecamatan Warunggunung tahun 2015.

Adapun nilai OR (Odds Ratio) yang diperoleh dalam penelitian ini sebesar 5.667. Hal ini dapat dikatakan bahwa lansia yang memiliki sikap negatif cenderung memiliki resiko hampir 6 kali lebih besar untuk tidak memanfaatkan Posbindu lansia dibandingkan dengan lansia yang memiliki sikap positif.

6. Hubungan Dukungan Keluarga Dengan Pemanfaatan PosbinduOleh Lansia.

Tabel 13

Hubungan Dukungan Keluarga Dengan Pemanfaatan Posbindu Oleh Lansia Di Ds Padasuka Wil Kerja Puskesmas Kec Warunggunung Kabupaten Lebak Tahun 2015

\begin{tabular}{|c|c|c|c|c|c|}
\hline \multirow{2}{*}{$\begin{array}{c}\text { Dukungan } \\
\text { keluarga }\end{array}$} & \multicolumn{2}{|c|}{$\begin{array}{c}\text { Pemanfaatan } \\
\text { Posbindu }\end{array}$} & \multirow{2}{*}{$\begin{array}{l}\text { Jum } \\
\text { lah }\end{array}$} & \multirow{2}{*}{$\begin{array}{c}\mathrm{P} \\
\text { Value }\end{array}$} & \multirow[t]{2}{*}{ OR } \\
\hline & kurang & baik & & & \\
\hline Kurang & $\begin{array}{c}24 \\
(75,0 \%)\end{array}$ & $\begin{array}{c}8 \\
(25,0 \%)\end{array}$ & $\begin{array}{c}32 \\
(100 \%)\end{array}$ & \multirow{3}{*}{0,038} & \multirow{3}{*}{$\begin{array}{r}3,37 \\
(1,19 \\
9.60)\end{array}$} \\
\hline Baik & $\begin{array}{c}16 \\
(47.1 \%)\end{array}$ & $\begin{array}{c}18 \\
(52.9 \%)\end{array}$ & $\begin{array}{c}34 \\
(100 \%) \\
\end{array}$ & & \\
\hline Jumlah & $\begin{array}{c}40 \\
(60.6 \%)\end{array}$ & $\begin{array}{c}26 \\
(39.4 \%)\end{array}$ & $\begin{array}{c}66 \\
(100 \%)\end{array}$ & & \\
\hline
\end{tabular}


Dari tabel 13diatas

menunjukkan bahwa lansia yang kurang memanfaatkan Posbindu proporsinya lebih besar pada lansia yang kurang memiliki dukungan keluarganya (75.0\%) dibandingkan padalansia yang memiliki dukungan keluarga (47.1\%).

Hasil uji ststistik dengan mengunakan uji Chi Square pada a $=0,05$ didapatkan nilai $\mathrm{P}$ sebesar $0,020 \quad(\mathrm{P}<0,05)$ yang berarti bahwa secara statistik terdapat hubungan yang bermakna antara dukungan dengan pemanfaatan Posbindu oleh lansia di Desa Padasuka Kecamatan Warunggunung tahun 2015.

Adapun nilai OR (Odds Ratio) yang diperoleh dalam penelitian ini sebesar 3.375. Hal ini dapat dikatakan bahwa lansia yang kurang memiliki dukungan keluarga cenderung memiliki resiko hampir 3 kali lebih besar untuk tidak memanfaatkan Posbindu lansia dibandingkan dengan lansia yang memiliki dukungan keluarga.

\section{Pembahasan}

1. Pemanfaatan Posbindu

Sesuai dengan hasil analisis univariat tentang pemanfaatan Posbindu oleh lansia di Desa Padasuka Kecamatan Warunggunung tahun 2015 didapatkan hasil dari 66 Lansia sebagian besar kurang memanfaatkan Posbindu sebesar $60.6 \%$. Indikator keberhasilan dalam pelayanan kesehatan kepada Lansia dalam salah satunya memiliki jumlah kelompok usia lanjut. (Kemenkes, 2010)

Dari hasil penelitian ini diperoleh informasi bahwa alasan terbesar responden tidak memanfaatkan Posbindu lansia yang terbesar adalah faktor ketidaktahuan lansia tentang pelayanan Posbindu.

Salah satu upaya yang dapat dilakukan dalam meningkatkan pemanfaatan Posbindu lansia dengan mensosialisasikan keberadaan Posbindu disetiap desa melalui pendekatan dan advokasi kepada pembuat kebijakan dalam hal ini kepala Desa dan tokoh masyarakat setempat, baik dalam pengadaan sarana maupun prasarana maupun menyusun perencanaan program 
Posbindu sesuai dengan kebutuhan masyarakat (lansia) dengan memperkuat dukungan dan meningkatkan pengetahuan kader dan lansia tentang hidup sehat, mandiri dan produktif.

2. Hubungan Umur dengan Pemanfaatan Posbindu

Berdasarkan hasil penelitian menunjukkan bahwa lansia yang kurang memanfaatkan

Posbinduproporsinya sedikit lebih besar pada lansia yang memiliki umur $>60$ tahun $(63,0 \%)$ dibandingkan padalansia yang memiliki umur 45-59 tahun (Pralansia) (59,0\%).

Hasil uji ststistik dengan mengunakan uji Chi Square pada $\alpha$ $=0,05$ didapatkan nilai $\mathrm{P}$ sebesar $0,744(\mathrm{P}>0,05)$ yang berarti bahwa secara statistik tidak terdapat hubungan yang bermakna antara umur dengan pemanfaatan Posbindu oleh lansia di Desa Padasuka Kecamatan Warunggunung tahun 2015

Penelitian serupa yang pernah dilakukan oleh Handayani di Kecamatan Ciomas Bogor tahun 2012 didapatkan hasil bahwa tidak terdapat hubungan antara umur dengan pemanfaatan Posbindu dengan nilai $\mathrm{P}=0,18$. Juga sesuai dengan hasil penelitian yang pernah dilakukan oleh Ariyani (2011) di Puskesmas Bambanglipuro Yogyakarta, didapatkan hasil bahwa tidak ada hubungan yang bermakna antara umur dengan pemanfaatan Posbindu lansia.

Menurut UU No.13 tahun 1998 tentang kesejahteraan Lansia menyatakan bahwa Lansia adalah seseorang yang sudah mencapai usia 60 tahun keatas. Pendapat Miller (1999) yang dikutif Hardywinoto (2007) menyatakan bahwa semakin tua umur seseorang maka semakin banyak fungsi organ tubuh yang mengalami gangguan/masalah yang berdampak pada kebutuhan klien akan pemeliharaan kesehatannya.

Proses Penuaan adalah suatu proses alami yang tidak dapat dihindari berjalan secara terus menerus dan berkesinambungan. Terjadinya perubahan anatomis, fisiologis dan biokimia pada tubuh erat kaitannya dengan fungsi dan kemampuan tubuh secara keseluruhan, umur berpengaruh 
terhadap tingkat pemanfaatan Pelayanan kesehatan. (Kemenkes 2010).

Menurut asumsi penulis bahwa kemampuan aktifitas seharihari pada usia lanjut dipengaruhi oleh umur itu sendiri. Semakin tua seseorang ketergantungannya semakin besar. Umur seseorang menunjukkan tanda kemauan dan kemampuan, atau bagaimana seseorang bereaksi terhadap ketidakmampuan melaksanakan aktifitas sehari-hari.

3. Hubungan Jenis kelamin dengan Pemanfaatan Posbindu

Berdasarkan hasil analisis univariat menunjukkanbahwa kurangnya pemanfaatan Posbindu oleh Lansia proporsinya lebih besar pada lansia yang memiliki jenis kelamin laki-laki(88,2\%) dibandingkan padalansia yang memiliki jenis kelamin perempuan $(51,0 \%)$.

Hasil uji ststistik dengan mengunakan uji Chi Square pada $\alpha$ $=0,05$ didapatkan nilai $\mathrm{P}$ sebesar $0,007 \quad(\mathrm{P}<0,05)$ yang berarti bahwa secara statistik terdapat hubungan yang bermakna antara jenis kelamin dengan pemanfaatan Posbindu oleh lansia di Desa Padasuka Kecamatan Warunggunung tahun 2015.

Adapun nilai OR (Odds Ratio) yang diperoleh dalam penelitian ini sebesar 7,200. Hal ini dapat dikatakan bahwa lansia yang memiliki jenis kelamin laki-laki cenderung memiliki resiko 7 kali lebih besar untuk tidak memanfaatkan Posbindu Lansia dibandingkan dengan lansia yang memiliki jenis kelamin perempuan.

Hasil penelitian ini sejalan dengan penelitian yang dilakukan oleh Zarniyeti (2011) yang menyatakan bahwa ada hubungan antara jenis kelamin dengan pemanfaatan Posbindu lansia.

Perempuan memiliki alat reproduksi yang lebih kompleks dibandingkan laki-laki dan secara sosial perbedaan-perbedaan ini menimbulkan pola penyakit dan pola akses terhadap pelayanan kesehatan berbeda. Pemanfaatan pelayanan kesehatan merupakan proses pengambilan keputusan yang dipengaruhi oleh beberapa faktor seperti nilai sosial budaya, 
pengetahuan, kesadaran akan pola hidup sehat, pola rekreasi dan pola pengambilan keputusan.

\section{Hubungan Tingkat Pendidikan} dengan pemanfaatan Posbindu

Berdasarkan hasil penelitian dengan analisis bivariat menunjukkan bahwa lansia yang kurang memanfaatkan Posbindu proporsinya lebih besar pada lansia yang memiliki pendidikan $\operatorname{rendah}(62.3 \%)$ dibandingkan padalansia yang memiliki pendidikan tinggi (40.0\%).

Hasil uji ststistik dengan mengunakan uji Chi Square pada $\alpha$ $=0,05$ didapatkan nilai $\mathrm{P}$ sebesar $0,327(\mathrm{P}>0,05)$ yang berarti bahwa secara statistik tidak terdapat hubungan yang bermakna antara pendidikan dengan pemanfaatan Posbindu oleh lansia di Desa Padasuka Kecamatan Warunggunung tahun 2015.

Menurut asumsi peneliti sendiri bahwa semakin tingi tingkat pendidikan seseorang akan meningkatkan pula ilmu pengetahuan dan informasi yang didapat.Hal ini menunjukkan semakin tinggi pendidikan seseorang, maka kebutuhan dan tuntutan terhadap pelayanan kesehatan semakin meningkat pula, semakin rendah tinkat pendidikan seseorang akan mengakibatkan mereka sulit menerima penyuluhan yang diberikan oleh tenaga kesehatan/tenga penyuluh

5. Hubungan Tingkat Pengetahuan dengan pemanfaatan Posbindu.

Berdasarkan hasil penelitian dengan analisis bivariat menunjukkanbahwa lansia yang kurang memanfaatkan Posbindu oleh Lansia proporsinya lebih besar pada lansia yang memiliki pengetahuan kurang $(94.1 \%)$ dibandingkan padalansia yang memiliki pengetahuan baik (49.0\%).

Hasil uji ststistik dengan mengunakan uji Chi Square pada $\alpha$ $=0,05$ didapatkan nilai $\mathrm{P}$ sebesar $0,001 \quad(\mathrm{P}<0,05)$ yang berarti bahwa secara statistik terdapat hubungan yang bermakna antara pengetahuan dengan pemanfaatan Posbindu oleh lansia di Desa Padasuka Kecamatan Warunggunung tahun 2015.

Adapun nilai OR (Odds Ratio) yang diperoleh dalam penelitian ini sebesar 16,667. Hal ini dapat dikatakan bahwa lansia yang 
memiliki pengetahuan kurang cenderung memiliki resiko hampir 17 kali lebih besar untuk tidak memanfaatkan Posbindu Lansia dibandingkan dengan lansia yang memiliki pengetahuan baik.

Tingkat pengetahuan erat hubungannya dengan tingkat pendidikan, Tingkat pendidikan yang rendah mengindikasikan kurangnya pengetahuan dan pemahaman responden tentang kesehatan. Pengaruh tingkat pendidikan sebagai suatu sistem mempunyai pengaruh dalam pembentukan sikap dikarenakan keduanya meletakkan dasar pengetahuan dan konsep moral diri individu. Individu yang berpendidikan lebih rendah (SD) memiliki pengetahuan yang lebih rendah sehingga kurang mengetahui manfaat dari Posyandu Lansia. Tingkat pendidikan responden yang berpendidikan tinggi dianggap mengerti dan mengetahui tentang gizi dan ilmu kesehatan serta pentingnya berkunjung ke Posyandu lansia (Rahayu, 2009). Oleh karena itu tingkat pendidikan yang rendah harus diimbangi dengan pemberian pengetahuan kesehatan agar wawasan kesehatan mereka lebih meningkat, misalnya dengan penyuluhan kesehatan.

\section{Hubungan Sikap dengan pemanfaatan Posbindu Lansia} Berdasarkan hasil penelitian dengan analisis bivariat menunjukkan bahwa Lansia yang kurang memanfaatkan Posbindu proporsinya lebih banyak pada lansia yang memiliki sikap negatif(85.0\%) dibandingkan padalansia yang memiliki sikap positif (50.0\%).

Hasil uji ststistik dengan mengunakan uji Chi Square pada $\alpha$ $=0,05$ didapatkan nilai $\mathrm{P}$ sebesar $0,007 \quad(\mathrm{P}<0,05)$ yang berarti bahwa secara statistik terdapat hubungan yang bermakna antara sikap dengan pemanfaatan Posbindu oleh lansia di Desa Padasuka Kecamatan Warunggunung tahun 2015.

Adapun nilai OR (Odds Ratio) yang diperoleh dalam penelitian ini sebesar 5.667. Hal ini dapat dikatakan bahwa lansia yang memiliki sikap negatif cenderung memiliki resiko hampir 6 kali lebih besar untuk tidak memanfaatkan Posbindu lansia 
dibandingkan dengan lansia yang memiliki sikap positif.

Hal ini sejalan dengan hasil penelitian Muzakkir (2012), menunjukkan bahwa terdapat hubungan yang signifikan antaraSikap Responden terhadap pemanfaatanposyandu lansia.

Sebagian besar responden lansiatentunya tetap

menginginkanbahwapelayanan

Posbindu dapatbertambah variasinya. Kegiatanyang dianggap monoton, sepertipemeriksaantekanan darah, penimbanganberat badan dan pengobatan dari petugaskesehatan apabila respondenmengeluh sakit.Dengan acara yangtidakberkembang menjadikan sikapresponden tidak baik.

Berdasarkan pada pengamatan danasumsi bahwa responden yang memilikisikap yang positif menjadikan respondenaktifdalam pemanfaatan Posbindu dibandingdengan responden yang memilikisikap yang negatif.
7. Hubungan Dukungan keluarga
dengan pemanfaatan Posbindu

Berdasarkan hasil penelitian dengan analisis bivariat menunjukkanbahwa lansia yang kurang memanfaatkan Posbindu proporsinya lebih besar pada lansia yang kurang memiliki dukungan keluarganya $(75.0 \%)$ dibandingkan padalansia yang memiliki dukungan keluarga (47.1\%).

Hasil uji ststistik dengan mengunakan uji Chi Square pada $\alpha$ $=0,05$ didapatkan nilai $\mathrm{P}$ sebesar $0,020(\mathrm{P}<0,05)$ yang berarti bahwa secara statistik terdapat hubungan yang bermakna antara dukungan dengan pemanfaatan Posbindu oleh lansia di Desa Padasuka Kecamatan Warunggunung tahun 2015.

Hasil penelitian ini sejalan dengan penelitian Muzakkir (2012), menunjukkan bahwa terdapat hubungan yang signifikan antara peran keluarga terhadap pemanfaatan posyandu lansia.

Menurut Maryam(2008), bahwadalam melakukan perawatan terhadaplansia, setiap anggota keluarga memilkiperanan yang sangat penting. Adabeberapa hal yang dapat 
dilakukan olehanggota keluarga mencegah terjadinya kecelakaanbaik dalam melaksanakanperanannya di dalam maupun di luar terhadap lansia yaitu :Melakukan rumah,pemeliharan kesehatan usia pembicaraan terarah, lanjut adalahtanggung jawab bersama,

mempertahankan

keluarga,membantu kehangatan melakukan persiapan makananbagi lansia, membantu dalam haltransportasi, membantu memenuhi sumbersumberkeuangan, memberikan kasihsayang, menghormati dan menghargai,bersikap sabar dan bijaksana terhadap prilaku lansia, memberikan kasih sayang,menyediakan waktu serta perhatian ,janganmenganggapnya sebagai beban,memberikan kesempatan untuk tinggalbersama, mintalah nasehat dalamperistiwaperistiwa penting, mengajaknyadalam acara-acara keluarga, membantumencukupi kebutuhannya, memberidorongan untuk tetap mengikuti kegiatankegiatandiluar rumah termasukpengembangan hobi, membantu mengaturkeuangan, mengupayakan saranatransportsi untuk kegiatan merekatermasuk rekreasi, memeriksakan kesehatan secara teratur, memberidorongan untuk tetap hidup bersih dansehat, memberiperhatian yang baik terhadap orang tuayang sudah lanjut maka anak-anak kitakelak akan bersikap yang sama.

Keluarga sangat berperan dalammemberikan informasi kepada lansiatentang pentingnya memanfaatkanposyandu lansia sehingga lansia bisamengikuti kegiatan posyandu. Dalamsemua tahap siklus kehidupan, dukungankeluarga membuat anggota keluargamampu berfungsi dengan berbagaikepandaian dan akal sehingga dapatmeningkatkan kesehatan dan adaptasianggota keluarga terhadap lingkungan luar.

Berdasarkan pada pengamatan dan asumsibahwa responden yang memiliki peran keluarga yang baik menjadikan respondenaktif dalam pemanfaatan posyandu lansiadibanding dengan responden yang tidakmemiliki peran keluarga. 


\section{Simpulan}

1. Sebagian besar lansia kurang memanfaatkan Posbindu di Desa Padasuka Wilayah Kerja Puskesmas Warunggunung tahun 2015

2. Sebagian besar lansia memiliki umur 45-59 tahun (Pra Lansia) di Desa Padasuka Wilayah Kerja Puskesmas Warunggunung tahun 2015.

3. Sebagian kecil lansia memiliki jenis kelamin laki-laki di Desa Padasuka Wilayah Kerja Puskesmas Warunggunung tahun 2015 .

4. Hampir seluruhnya tingkat pendidikan lansia rendah di Desa Padasuka Wilayah Kerja Puskesmas Warunggunung tahun 2015.

5. Masih banyak lansia memiliki sikap negatif terhadap posbindu di Desa Padasuka Wilayah Kerja Puskesmas Warunggunung tahun 2015.

6. Hampir setengahnya lansia kurang mendapat dukungan keluarga di Desa Padasuka Wilayah Kerja Puskesmas Warunggunung tahun 2015.
7. Terdapat hubungan yang bermanakna antara jenis kelamin, pengetahuan, sikap dan dukungan keluarga dengan pemanfaatan Posbindu di Desa Padasuka Wilayah Kerja Puskesmas Warunggunung tahun 2015.

8. Tidak Terdapat hubungan yang bermanakna antara umur dan pendidian dengan pemanfaatan Posbindu di Desa Padasuka Wilayah Kerja Puskesmas Warunggunung tahun 2015.

\section{Daftar Pustaka}

Azwar, S, 2009 Sikap Manusia Teori Dan Pengukurannya edisi 2, Pustaka Pelajar, Jakarta.

Dinas Kesehatan Kabupaten lebak, 2012, Profil Kesehatan Kabupaten Lebak tahun 2014Dinkes Kabupaten Lebak

Fatmah, 2010, Gizi Usia Lanjut Erlangga, Jakarta

Fitrah, Dwi W. (2010) Memahami Kesehatan Pada Lansia. Trans Info Medika F. Jakarta.

Handayani, Dwi Eka, 2012, Pemanfaatan Pos Pembinan terpadu Oleh Usia Lanjut di Kecamatan Ciomas Kabupaten Bogor tahun 2012 dan Faktor yang Berhubungan, Skripsi, FKM, UI, Depok. 
Maryam, R Siti, dkk. 2008, Mengenal Usia Lanjut dan Perawatannya, Salemba Medika, Jakarta

Maryam, R, Siti dkk. 2010, Buku Panduan Bagi KaderPosbindu Lansia, Salemba Medika, Jakarta.

Muzakkir, 2012 Faktor-Faktor Yang Mempengaruhi

PemanfaatanPosyandu Lansia Di Desa Ilekimok Kecamatan Atadei Kabupaten Lembata NTT, STIKes Hasanuddin Makasar.

Notoatmodjo, Soekidjo, 2003, Pendidikan dan Perilaku Kesehatan, PT Rineka Cipta, Jakarta

Metode Penelitian Kesehatan. Jakarta : Rineka Cipta. 2005 , Promosi Kesehatan Teori dan Aplikasi, Rineka Cipta, Jakarta.

Puskesmas Warunggunung, 2015. Laportan Kegiatan Posbindu bulan Februari 2015.

Siti Bandiyah., 2009, Lanjut Usia dan Keperawatan Gerontik, Nuha Medika ,Jogjakarta.

Sugiyono. 2010. Statistika untukPenelitian. Bandung :Alfabeta.

Rahayu, Anggorowati. 2009. Analisis Kecukupan Energi dan Protein terhadap Status Gizi Lansia di
Posyandu Lansia "Ngesti Basuki", danukusuman, surakarta. Program D-IV Analis Kesehatan Fakultas Ilmu Kesehatan Universitas Setia Budi Surakarta. 